\title{
PENGARUH PENGETAHUAN PRODUK, LABEL ORGANIK KOMUNITAS, DAN PERILAKU PENCARIAN INFORMASI TERHADAP MINAT BELI PRODUK ORGANIK DI KOMUNITAS ORGANIK INDONESIA
}

\author{
THE INFLUENCE OF PRODUCT KNOWLEDGE, COMMUNITY-ASSESSED \\ ORGANIC LABEL, AND INFORMATION SEEKING BEHAVIOUR TOWARDS \\ PURCHASE INTENTION OF ORGANIC PRODUCTS IN KOMUNITAS ORGANIK \\ INDONESIA
}

\author{
Goldie Shaumy Lestari*, Agriani Hermita Sadeli, Pandi Pardian, Sri Fatimah \\ Program Studi Agribisnis, Fakultas Pertanian, Universitas Padjadjaran, \\ Jl. Raya Bandung Sumedang Km 21 \\ *E-mail: gshaumy@yahoo.com \\ (Diterima 07-04-2021; Disetujui 03-06-2021)
}

\begin{abstract}
ABSTRAK
Isu lingkungan dan keamanan pangan menyebabkan berkembangnya praktik pertanian organik secara global, tanpa terkecuali di Indonesia. Salah satu permasalahan dalam pertanian organik di Indonesia adalah biaya sertifikasi organik yang mahal dan prosesnya yang panjang. Sebagai solusi permasalahan ini, Komunitas Organik Indonesia berinisiatif untuk membuat program kurasi bernama White Flower Label untuk menjamin bahwa produk-produk yang dipasarkan anggotanya benar-benar organik. Penelitian ini dilakukan dengan desain kuantitatif dan metode survey dengan instrumen kuesioner. Ukuran sampel yang digunakan adalah sebanyak 30 responden. Teknik yang digunakan adalah teknik eksplanatori untuk mengetahui bagaimana pengaruh pengetahuan produk (X1), label organik komunitas (X2), dan perilaku pencarian informasi (X3) terhadap minat beli (Y). Hasil penelitian menunjukkan bahwa hanya variabel perilaku pencarian informasi (X3) yang memiliki pengaruh signifikan terhadap minat beli, sementara variabel pengetahuan produk (X1) dan label organik komunitas (X2) tidak memiliki pengaruh yang signifikan.
\end{abstract}

Kata kunci: label organik, komunitas, minat beli, pengetahuan produk

\section{ABSTRACT}

Environmental and food security issues has caused organic farming practice to grow globally, including in Indonesia. One of the problems in Indonesia's organic farming is the cost of organic certification as well as it's long process. As a solution to this problem, Komunitas Organik Indonesia took an initiative to form a curration program called White Flower Label to guarantee that their member's products are indeed organic. This study uses quantitative design and a survey method using questionnaire. The sample size used was 30 respondents. The technique used is explanatory, to explain how product knowledge (X1), community-assessed organic label (X2), and information seeking behaviour (X3) influence purchase intention (Y). The results shows that only information seeking behaviour (X3) has a significant effect on purchase intention, while product knowledge (XI) and community-assessed organic label doesn't have any significant effect.

Keywords: organic label, community, purchase intention, product knowledge

\section{PENDAHULUAN}

Keamanan pangan menjadi topik yang kian sering diberitakan sebagai respon terhadap maraknya isu-isu lingkungan dalam sektor pertanian. Penggunaan bahan-bahan kimia seperti 
pupuk dan pestisida sebagai input produksi dalam praktik pertanian konvensional memunculkan kekhawatiran pada masyarakat bukan hanya mengenai dampak penggunaan bahan-bahan tersebut terhadap lingkungan namun juga dampak jika bahan-bahan tersebut terkonsumsi bersamaan dengan dikonsumsinya hasil pertanian.

Isu lingkungan dan keamanan pangan yang meliputi sektor pertanian perlahan-lahan mulai menumbuhkan kesadaran pada masyarakat sebagai konsumen untuk lebih memperhatikan keamanan produk-produk hasil pertanian atau olahannya, dan pada akhirnya menciptakan suatu kebutuhan untuk mempromosikan sistem pertanian organik (Gupta, 2017). Gupta (2017) mendefinisikan pertanian organik sebagai sebuah metode berkelanjutan dalam pertanian yang menggunakan teknik-teknik alami seperti crop rotation, vermi-composting, bio-fertilizers, crop management, animal manure, off-farm organic waste, crop residues, dan lain sebagainya daripada bahan kimia sehingga kualitas tanah tetap terjaga dan hasil pertanian aman dikonsumsi.

Berkembangnya praktik pertanian dengan sistem organik tiap tahunnya berdampak pada pola hidup masyarakat sebagai konsumen produk-produk hasil pertanian. Menurut Survei FiBL (2019), Pada tahun 2012 hingga 2017, luas lahan pertanian global yang dikelola secara organik menunjukan tren yang meningkat cukup signifikan. Dari 36,8 juta Ha pada tahun 2012 menjadi 69,8 juta Ha di tahun 2017. Hal ini mengindikasikan adanya peningkatan permintaan akan produkproduk pertanian organik dalam skala global. Indonesia sendiri merupakan negara dengan luas area pertanian organik terbesar ke-4 di Asia pada tahun 2017.

Pertanian organik di Indonesia secara umum mendapat respon yang baik dari masyarakat dan didukung oleh pemerintah. Hal ini ditandai dengan diluncurkannya program 1000 Desa Organik oleh Kementrian pertanian, yang diharapkan dapat terwujud pada tahun 2020. Menurut Aliansi Organis Indonesia atau AOI (2019), hal lain yang menandai berkembangnya pertanian organik di Indonesia adalah angka pertumbuhan bahan makanan organik yang mencapai $15-20 \%$ tiap tahunnya.

Hal yang kerap menjadi kendala dalam perkembangan pertanian organik Indonesia adalah persoalan sertifikasi, khususnya untuk produsen berskala kecil 
(Mayrowani, 2012). Sertifikasi produk pertanian organik diperlukan untuk menjamin bahwa produk benar-benar diproses secara organik dan sesuai dengan standar yang ditetapkan, sehingga fungsi dari sertifikasi adalah sebagai bentuk perlindungan terhadap konsumen (AOI, 2011). Menurut Fransisco et al (2009) dalam Rodrigues et al (2016), sertifikasi organik merupakan salah satu atribut yang paling penting bagi konsumen dalam membeli produk organik.

Permasalahan dalam sertifikasi produk organik adalah alurnya yang sangat panjang dan biaya yang perlu dikeluarkan cukup besar. Biaya yang ditetapkan lembaga swasta untuk pengajuan sertifikasi satu produk berkisar antara Rp15.000.000 - Rp30.000.000, tergantung luas lahan dan jenis komoditas. Sertifikat organik yang diberikan akan berlaku selama tiga tahun, karenanya produsen perlu melakukan perpanjangan dan kembali harus mengeluarkan biaya sebesar Rp7.500.000 - Rp15.000.000.

Selain sertifikasi oleh lembaga swasta, terdapat juga sistem penjaminan berbasis komunitas atau menurut International Federation of Organic Agriculture Movements (IFOAM) dikenal sebagai Participatory Guarantee System (PGS). Salah satu sistem penjaminan partisipatif yang dikembangkan di Indonesia adalah program White Flower Label yang dikembangkan oleh Komunitas Organik Indonesia (KOI). Komunitas Organik Indonesia adalah komunitas yang berdiri sejak tahun 2007 dan beranggotakan para penggiat, pelaku, dan peminat produkproduk dan gaya hidup organik.

Label organik merupakan komponen penting dalam produk organik, karena fungsinya sebagai identitas yang menjamin bahwa suatu produk benarbenar diproduksi secara organik. Adanya label organik diharapkan akan dapat memberikan rasa aman pada konsumen produk organik, yang kemudian akan menimbulkan kepercayaan terhadap produk. Mengacu pada pernyataan Stanton dan Futrell (1987) mengenai klasifikasi label, label organik dapat diklasifikasikan sebagai descriptive label karena fungsinya sebagai pemberi informasi mengenai:

1. Proses produksi produk sesuai dengan standar organik.

2. Bahan baku produk sesuai dengan standar organik.

3. Efek yang ditimbulkan produk sesuai dengan standar organik. 
Sertifikasi dan pelabelan produk organik oleh komunitas di Indonesia saat ini belum banyak dilakukan. Karenanya, penting untuk mengetahui sejauh mana sebenarnya pengaruh dari label organik yang diberikan oleh komunitas bagi konsumen. Berkaitan dengan hal tersebut, tingkat pengetahuan konsumen akan produk organik dengan label komunitas juga perlu ditelisik lebih lanjut.

Menurut Peter dan Olson (1999), pengetahuan produk terbagi menjadi tiga, yakni:

1. Pengetahuan tentang karakterisktik atau atribut produk (perangkat ciri).

2. Pengetahuan tentang manfaat produk (perangkat manfaat).

3. Pengetahuan tentang kepuasan yang diberikan produk bagi konsumen (nilai kepuasan).

Ketika konsumen memiliki pengetahuan mengenai suatu produk, maka ia akan dapat membuat keputusan dengan lebih baik dan lebih efisien, karena informasi mengenai produk telah 'diolah' terlebih dahulu sebelum penentuan keputusan. Perolehan informasi dapat terjadi secara 'disengaja' dan 'tidak disengaja'. Hal ini dikenal juga sebagai perilaku informasi pasif (passive information behaviour) dan perilaku informasi aktif (active information behaviour). Perilaku informasi aktif dapat disebut juga sebagai perilaku pencarian informasi (information seeking behaviour), yang kemudian secara sederhana dapat didefinisikan sebagai suatu proses dimana seseorang secara sengaja berusaha untuk mengubah kondisi pengetahuan mereka (state of knowledge) (Odongo, 2005).

Mengadopsi konsep Information Acceptance Model (IACM) yang diusulkan oleh Erkan dan Evans (2016) dalam kaitannya dengan pencarian informasi, dan menghubungkannya dengan teori perilaku informasi yang diusulkan Wilson (1999), hal-hal yang menjadi dimensi perilaku pencarian informasi dapat dirumuskan sebagai berikut:

1. Kebutuhan akan informasi (needs of information).

2. Kegunaan informasi (information usefulness).

3. Adopsi informasi (information adoption).

4. Intensi pembelian (purchase intention).

Menurut Schiffman dan Kanuk (2008), minat beli merupakan sikap senang atau ketertarikan seseorang terhadap suatu objek yang akan membuatnya berusaha untuk 
mendapatkan objek tersebut dengan cara membayar atau pengorbanan (membeli). Seperti telah diketahui, minat beli akan muncul pada tahap evaluasi alternatif, yakni ketika konsumen telah membandingkan nilai-nilai yang terdapat dalam suatu produk. Apabila konsumen merasa lebih banyak mendapatkan manfaat dari suatu produk dibandingkan pengorbanan yang perlu dikeluarkan, maka motivasi untuk membeli produk tersebut akan tinggi.

Menurut Ferdinand (2002), minat beli dapat diidentifikasi melalui indikator-indikator sebagai berikut: (1) Transaksional, (2) Referensial,

Preferensial, dan (4) Eksploratif.

Tujuan penelitian ini adalah untuk mengetahui bagaimana pengaruh pengetahuan produk yang dimiliki konsumen mengenai produk dengan label organik komunitas (WFL) dan pencantuman label itu sendiri terhadap minat beli. Pengaruh perilaku pencarian informasi terhadap minat beli juga dikaji dalam penelitian ini.

\section{METODE PENELITIAN}

Penelitian dilakukan pada konsumen Komunitas Organik Indonesia yang tergabung dalam grup Komunitas Selaras Alam 1 dan 2 pada aplikasi
Whatsapp, dan menggunakan metode kuantitatif dengan teknik eksplanatori. Variabel dependen dalam penelitian ini adalah pengetahuan produk (X1), label organik komunitas (X2), dan perilaku pencarian informasi (X3), dengan variabel dependen minat beli (Y).

Sampel penelitian diambil secara non-acak dengan convenience sampling, karena adanya syarat yang harus dipenuhi yakni sampel harus merupakan anggota dari grup Whatsapp Komunitas Selaras Alam 1 atau 2, dan calon responden harus membalas pesan permohonan pengisian kuesioner sebagai syarat bahwa responden bersedia berpartisipasi dalam penelitian. Jumlah sampel penelitian adalah sebanyak 30, yang didasarkan pada kaidah 'rule of ten' oleh Hair et al (2011).

Teknik pengumpulan data dilakukan dengan pengisian kuesioner yang diberikan pada responden melalui pesan pada aplikasi Whatsapp secara satu-persatu. Kuesioner penelitian berisi pertanyaan-pertanyaan terkait variabel penelitian dan menggunakan alat bantu berupa skala likert. Skala likert memiliki lima skor, dengan angka 1 (Sangat Tidak Setuju) merupakan skor terendah dan angka 5 (Sangat Setuju) merupakan skor tertinggi. 
Data selanjutnya akan dianalisis menggunakan analisis persamaan struktural atau Structural Equation Modeling (SEM) berbasis varian dengan bantuan software SmartPLS. Analisis dilakukan dengan uji validitas konvergen dan diskriminan, uji reliabilitas, pengujian model struktural, uji Goodness of Fit (GoF), bootstrapping dan path coefficient, uji koefisien determinasi $\left(\mathrm{R}^{2}\right)$, dan uji parsial (uji-t).

\section{HASIL DAN PEMBAHASAN}

\section{Karakteristik Responden}

Karakteristik responden penelitian dibagi secara demografis, yakni jenis kelamin, usia, pendidikan terakhir, pendapatan perbulan, status perkawinan, pekerjaan, tempat tinggal, dan jumlah anggota keluarga. Adapun karakteristik responden yang didapatkan berdasarkan hasil penelitian adalah sebagai berikut.

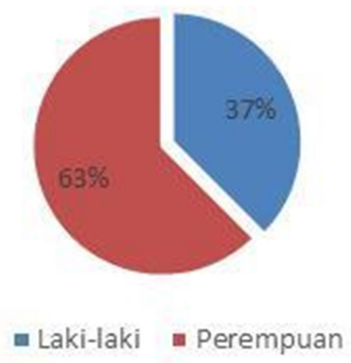

\section{Gambar 1. Jenis Kelamin Responden}

Berdasarkan Gambar 1, diketahui bahwa mayoritas responden berjenis kelamin perempuan. Menurut Kranjac et al (2017), lebih banyaknya perempuan yang tertarik untuk mengkonsumsi produk organik disebabkan oleh sifat perempuan yang lebih peduli terhadap penampilan fisik dan status kesehatan, juga karena perempuan cenderung lebih mudah dan tidak ragu mengeluarkan biaya. Hal ini juga dikarenakan perempuan umumnya bertanggungjawab untuk berbelanja kebutuhan dapur (Rasmikayanti, et al., 2020).

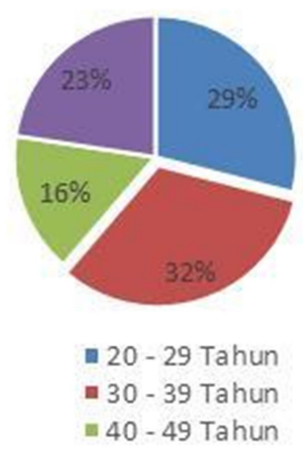

\section{Gambar 2. Usia Responden}

Mayoritas responden berada pada rentang usia 30 - 39 tahun, atau termasuk dalam usia dewasa. Kalangan dewasa umumnya telah memiliki pemahaman yang lebih baik, sehingga informasi mengenai produk-produk yang berkaitan dengan lingkungan dan kesehatan dapat lebih diproses dengan baik (Airine, 2010). 


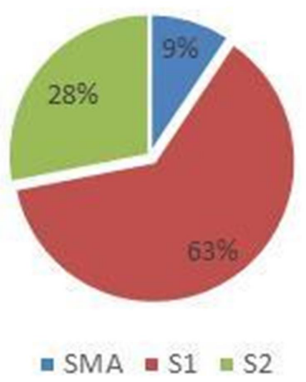

\section{Gambar 3. Tingkat Pendidikan Responden}

Gambar 3 menunjukkan bahwa mayoritas responden memiliki gelar sarjana. Hal ini menandakan bahwa banyak konsumen produk KOI yang memiliki latar belakang pendidikan tinggi. Tingkat pendidikan yang tinggi berarti konsumen memiliki tingkat pengetahuan yang lebih baik mengenai berbagai hal, sehingga memungkinkan adanya kecenderungan untuk memilih produk organik karena dinilai lebih sehat, bergizi, dan berkualitas dibandingkan produk konvensional (Rasmikayanti et al, 2020).

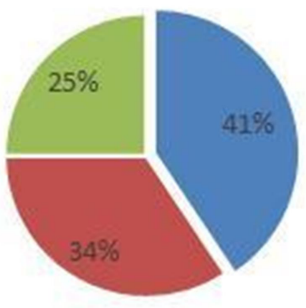

- Rp1.500.000 - Rp5.000.000

- Rp5.500.000-Rp10.000.000

II $>\mathrm{RP} 10.000 .000$

Gambar 4. Pendapatan Bulanan Responden

Gambar 4 menunjukkan bahwa mayoritas responden memiliki penghasilan bulanan dengan rentang Rp1.500.000 - Rp5.000.000, atau termasuk tinggi. Menurut Stolz et.al. (2011) dalam Kranjac et al (2017), pendapatan yang tinggi memiliki keterkaitan yang signifikan dengan preferensi pembelian produk organik.

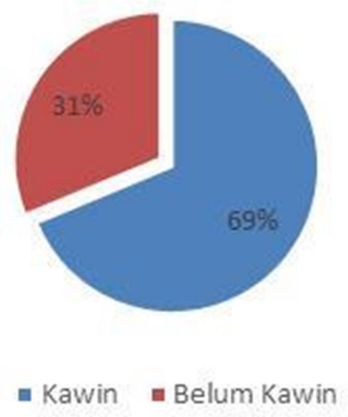

Gambar 5. Status Perkawinan Responden Berdasarkan Gambar 5, dapat dilihat bahwa mayoritas responden berstatus kawin. Konsumen yang berstatus kawin memiliki kecenderungan untuk lebih peduli dan hati-hati dalam memilih produk yang akan menjadi konsumsi keluarga, oleh karena itu umumnya seseorang yang telah berkeluarga memiliki kecenderungan untuk membeli produk organik (Airine, 2010). 


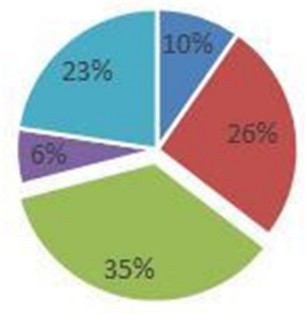

$$
\begin{aligned}
& \text { - PNS/BUMN/TNI/POLRI } \\
& \text { - Wiraswasta } \\
& \text { - Pegawai/Karyawan swasta } \\
& \text { - IRT } \\
& \text { - Lainnya }
\end{aligned}
$$

\section{Gambar 6. Pekerjaan Responden}

Berdasarkan Gambar 6, dapat terlihat bahwa mayoritas responden berprofesi sebagai pegawai atau karyawan swasta. Apabila dikaitkan dengan karakteristik jenis kelamin, ini berarti banyak dari konsumen produk KOI yang merupakan wanita yang bekerja. Hal ini berbeda dengan penelitian sejenis yang menyatakan bahwa umumnya konsumen produk organik berprofesi sebagai ibu rumah tangga, karena ibu rumah tangga dianggap bertanggung jawab untuk berbelanja bahan-bahan pangan (Airine, 2010).

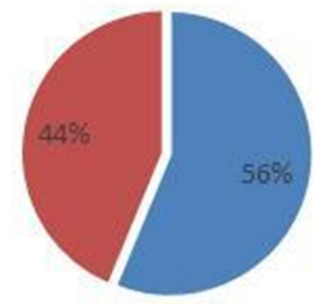

wabodetabek Diluar Jabodetabek

Gambar 7. Tempat Tinggal Responden
Gambar 7 menunjukkan bahwa mayoritas responden bertempat tinggal di Jabodetabek. Lebih banyaknya jumlah konsumen didalam grup KSA yang bertempat tinggal di Jabodetabek adalah karena grup KSA 1 dan 2 merupakan grup konsumen yang pertama kali dibuat, saat cabang KOI masih belum sebanyak saat ini, sehingga lebih banyak anggotanya merupakan konsumen yang mengetahui KOI dari cabang pusat yang berlokasi di Jakarta.

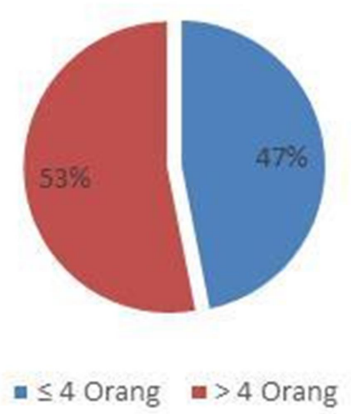

Gambar 8. Jumlah Anggota Keluarga Responden

Gambar 8 menunjukkan bahwa mayoritas responden memiliki jumlah anggota keluarga sebanyak $>4$ orang, yang berarti termasuk kedalam kategori keluarga sedang ( $5-6$ orang) atau besar (> 7 orang).

\section{Analisis Data}

Data-data yang didapatkan diolah dengan metode SEM-PLS menggunakan bantuan aplikasi SmartPLS. Berdasarkan hasil olah data, diketahui bahwa minat beli responden dipengaruhi oleh perilaku 
pencarian informasi (Tabel 1). Pada program SmartPLS, hipotesis penelitian dapat diuji salah satunya dengan melihat nilai P-Values. Apabila nilai P-Values <
0,05, maka hipotesis dapat diterima. Sebaliknya, apabila nilai P-Values lebih besar dari 0,05 maka berarti hipotesis ditolak.

Tabel 1. Hasil Uji Hipotesis

\begin{tabular}{lcccc}
\hline & & t-statistics $(|\mathrm{O} / \mathrm{STDEV}|)$ & P-Values & Hasil \\
\hline $\begin{array}{l}\text { Pengetahuan Produk }=> \\
(\mathrm{X} 1)=>(\mathrm{Y} 1)\end{array}$ & 0,265 & 0,791 & Ditolak \\
$\begin{array}{l}\text { Label Organik Komunitas }=>\text { Minat Beli } \\
(\mathrm{X} 2)=>(Y 1)\end{array}$ & 0,090 & 0,928 & Ditolak \\
$\begin{array}{l}\text { Perilaku Pencarian Informasi }=>\text { Minat Beli } \\
(\mathrm{X} 3)=>(Y 1)\end{array}$ & 4,293 & 0,000 & Diterima \\
\hline Sumber: Analisis Data Primer (2020) & & &
\end{tabular}

Berdasarkan hasil uji hipotesis pertama yang dapat dilihat pada tabel 1, nilai P Values menunjukkan hasil sebesar 0,791 atau lebih besar dari 0,05, yang berarti $\mathrm{H} 1_{1}$ ditolak dan $\mathrm{H} 1_{0}$ diterima. Hal ini berarti bahwa Pengetahuan Produk secara parsial tidak memiliki pengaruh yang signifikan terhadap Minat Beli produk dengan White Flower Label. Hasil ini berlawanan dengan teori umum dimana pengetahuan produk akan mempengaruhi minat untuk melakukan pembelian.

Tidak signifikannya pengaruh pengetahuan produk terhadap minat beli bisa jadi disebabkan oleh pengukuran pengetahuan konsumen yang lebih didasarkan pada persepsi (self-assessed) sehingga pengetahuan konsumen yang didapat bersifat subjektif, yang berarti belum tentu konsumen benar-benar mengetahui (secara objektif) apa yang mereka pikir ketahui (Recker dan Saleem, 2014). Menurut White et al (1994) dalam Recker dan Saleem (2014), pengetahuan produk yang bersifat subjektif umumnya lebih didasarkan pada pengalaman konsumen dalam menggunakan produk (past experience), sehingga tidak dapat menggambarkan pengetahuan produk yang sebenarnya.

Hal lain yang mungkin menyebabkan pengaruh pengetahuan produk terhadap minat beli menjadi tidak signifikan dapat berkaitan dengan bagaimana konsumen memperoleh informasi mengenai produk. Konsumen dengan pengetahuan produk yang tinggi bisa jadi memperoleh informasi tersebut bukan berdasarkan keinginannya sendiri, melainkan dari pihak lain secara tidak disadari. Karena didapatkan secara tidak disadari, bisa jadi pengetahuan ini tidak menimbulkan adanya dorongan pada 
konsumen untuk melakukan pembelian, meskipun konsumen memiliki pengetahuan yang baik mengenai produk.

Selanjutnya, hasil uji hipotesis kedua menunjukan nilai $\mathrm{P}$ Values sebesar 0,928 atau lebih besar dari 0,05 , yang berarti $\mathrm{H} 2{ }_{1}$ ditolak dan $\mathrm{H} 2_{0}$ diterima. Hal ini berarti bahwa Label Organik Komuntas secara parsial tidak memiliki pengaruh yang signifikan terhadap Minat Beli. Wang, et.al (2019) berpendapat, terlepas dari fakta bahwa sertifikasi dan labelisasi produk dapat menjadi sarana penyampaian informasi mengenai kualitas produk pada konsumen, tidak berarti bahwa konsumen akan secara langsung mempercayai label tersebut.

Minat beli konsumen terkait dengan pencantuman label organik juga mungkin dipengaruhi oleh kecenderungan konsumen untuk lebih fokus pada tanda intrinsik produk (intrinsic cues). Label organik (extrinsic cue) mungkin tidak dapat mempengaruhi niat beli konsumen jika terdapat tanda intrinsik yang cukup menonjol pada produk, misalnya bentuk yang tidak biasa pada produk sayursayuran atau buah-buahan organik, atau pada produk olahan misalnya rasa produk yang kurang menarik (Loebnitz, et.al, 2015).
Kemudian hasil uji hipotesis ketiga menunjukan nilai P Values menunjukkan hasil sebesar 0,000 atau lebih kecil dari 0,05, yang berarti $\mathrm{H} 3_{1}$ ditolak dan $\mathrm{H} 3_{0}$ diterima. Hal ini berarti bahwa Perilaku Pencarian Informasi secara parsial memiliki pengaruh yang signifikan terhadap Minat Beli.

$$
\text { Sebagaimana }
$$

diketahui, ketertarikan individu akan suatu hal dapat mendorong dilakukannya pencarian informasi mengenai hal terkait, yang berarti adanya usaha untuk mengubah tingkat pengetahuan (Odongo, 2005). Selanjutnya, informasi yang didapat akan mempengaruhi sikap awal individu mengenai hal menarik tersebut (Zepeda dan Deal, 2009). Hal ini juga berlaku dalam pembentukan minat beli konsumen. Ketika suatu produk menarik perhatian konsumen, mereka akan mencari informasi mengenai produk tersebut, kemudian bergantung pada informasi yang didapatkan, niat awal konsumen untuk membeli produk dapat berubah menjadi semakin kuat atau justru semakin lemah.

\section{KESIMPULAN DAN SARAN}

Berdasarkan identifikasi masalah dan hasil pembahasan mengenai analisis pengaruh pengetahuan produk, label 
organik komunitas, dan perilaku pencarian informasi terhadap minat beli produk dengan WFL, maka dapat ditarik kesimpulan sebagai berikut:

1. Mayoritas responden berjenis kelamin wanita $(62,5 \%)$, memiliki rentang usia 20 - 29 tahun (28,1\%), Bergelar Sarjana (62,5\%), dan berpenghasilan Rp1.500.000 - Rp5.000.000 perbulan. Responden juga mayoritas berstatus kawin $(68,8 \%)$ dengan jumlah anggota keluarga $\geq 4$ orang $(53,1 \%)$, berprofesi sebagai karyawan swasta (34,4\%), dan bertempat tinggal di Jabodetabek (56,3\%).

2. Pengetahuan produk tidak mempengaruhi minat beli, bisa jadi disebabkan oleh pengukuran pengetahuan konsumen yang lebih didasarkan pada persepsi (selfassessed) sehingga pengetahuan konsumen yang didapat bersifat subjektif.

3. Pencantuman White Flower Label tidak mempengaruhi minat beli. Minat beli konsumen produk dengan WFL mungkin lebih dipengaruhi oleh tanda intrinsik produk.

4. Perilaku pencarian informasi memiliki pengaruh yang signifikan terhadap minat beli, karena konsumen merasa informasi yang ditemukan mengenai produk dengan WFL informatif.

KOI dapat berupaya untuk lebih meningkatkan pengetahuan produk konsumen, khususnya mengenai manfaat produk. Hal ini dapat dilakukan misalnya dengan lebih menggiatkan workshop bukan hanya mengenai produk secara langsung namun juga mengenai masalahmasalah kesehatan yang dapat diatasi atau diredakan oleh produk yang dipasarkan.

KOI juga dapat lebih rutin mengupdate akun-akun pada media sosial dan e-commerce, agar konsumen dapat lebih mudah memperoleh informasi terbaru.

\section{DAFTAR PUSTAKA}

Airine, Therezia. 2010. Analisis Perilaku Konsumen Sayuran Organik (Studi Kasus: Giant Botani Square, Kota Bogor, Jawa Barat). Skripsi Sarjana Departemen Agribisnis Fakultas Ekonomi dan Manajemen, Institut Pertanian Bogor.

Aliansi Organis Indonesia. 2017. Statistik Pertanian Organik Indonesia 2016. Bogor. Aliansi Organis Indonesia.

Erkan, Ismail and Evans, Chris. 2016. "The influence of eWOM in social media on consumers' purchase intentions: An extended approach to information adoption." Computers in Human Behavior, Vol. 61, p. $47-55$.

FiBL, \& IFOAM. 2019. The World of Organic Agriculture - Statistic \& Emerging Trends 2019. 
Switzerland. Die Deutsche Bibliothek.

Gupta, S. 2017. "Food Safety and Organic Farming." MOJ Food Processing \& Technology. Vol. 4, No. 3 , p. $81-83$.

Hair J. F., C. M. Ringle and M. Sarstedt. 2011. "PLS-SEM: Indeed a Silver Bullet." Journal of Marketing Theory and Practice, Vol. 19, No. 2, p. $139-152$.

Kranjac M., J. V. Tankosić and M. Knežević. 2017. "Profile of Organic Food Consumers." Ekonomika Poljoprivrede, Vol. 64, No. 2, p. 497 - 514.

Loebnitz N., G. Schuitema and K. G. Grunert. 2015. "Who Buys Oddly Shaped Food and Why? Impacts of Food Shape Abnormality and Organic Labeling on Purchase Intentions." Psychology \& Marketing, Vol. 32, No. 4, p. 408 421.

Mayrowani, Henny. 2012. "Pengembangan Pertanian Organik di Indonesia." FORUM PENELITIAN AGRO EKONOMI, Vol. 30, No. 2, p. $91-108$.
Peter, J. Paul dan Olson, Jerry C. 1999. Perilaku Konsumen dan Strategi Pemasaran (Consumer Behaviour). Edisi Keempat. Jil. I. Terj. Damos Sihombing dan Yati Sumiharti (ed). Jakarta: Penerbit Erlangga.

Rasmikayanti, E., et al. 2020. "Keterkaitan Antara Karakteristik Konsumen dengan Tingkat Kepuasan Mereka dalam Melakukan Pembelian Sayur Organik di Pasar Modern Kota Medan." Jurnal Agribisnis dan Sosial Ekonomi Pertanian UNPAD, Vol. 5, No. 1, p. 104 - 114.

Recker, A. And Saleem, B. 2014. The Effects of Consumer Knowledge and Values on Attitudes and Purchase Intentions. Master Thesis School of Business and Economics, Umeå University.

Schiffman, Leon G. dan Kanuk, Leslie Lazar. 2007. Perilaku Konsumen (Consumer Behaviour). Edisi Ketujuh. Terj. Zoelkifli Kasip. Jakarta: PT. Indeks.

Stanton, William J. and Futrell, Charles. 1987. Fundamentals of Marketing. New York: McGraw-Hill. 